\title{
The epidemiology of noncommunicable respiratory disease in sub-Saharan Africa, the Middle East, and North Africa
}

\author{
Rana Ahmed ${ }^{1,2}$, Ryan Robinson ${ }^{2}$, Kevin Mortimer ${ }^{2}$ \\ 1. The Epidemiological Laboratory, Khartoum, Sudan \\ 2. Liverpool School of Tropical Medicine, Liverpool, United Kingdom \\ Correspondence: Mrs Rana Ahmed (rana.atta85@gmail.com)
}

\begin{abstract}
Noncommunicable diseases (NCDs) are a major and increasing global health issue. The World Health Organization (WHO) estimates that NCDs represent $63 \%$ of all global deaths of which 3.9 million are due to chronic respiratory diseases (CRDs) and Chronic Obstructive Pulmonary Disease (COPD) in particular. COPD is now the third most common cause of death globally; $90 \%$ of these deaths occur in Low and Middle Income Countries (LMICs). COPD affects 329 million people, almost 5\% of the world's population. In addition, asthma affects 334 million people, again representing almost 5\% of the world's population. There is limited literature published on the epidemiology of COPD and Asthma from Sub-Saharan Africa (SSA) and Middle East and North Africa (MENA). Both diseases are under-diagnosed and underestimated in both SSA and MENA regions. The burden of COPD in sub-Saharan Africa is disputed and reports offer variable prevalence estimates, ranging from $4.1 \%$ to almost $22.2 \%$. SSA and MENA countries report similar mortality rates from COPD of 18 per 100,000 population (2001 data). Asthma is a less common cause of death than COPD but is a major cause of morbidity; WHO estimates that there are 250,000 deaths per year from asthma, mainly in LMICs and it remains in the top twenty causes of disability in children globally. Risk factors for CRD are genetic and environmental; the latter dominated by air pollution exposures including tobacco smoke, household air pollution, outdoor air pollution and occupational exposures.
\end{abstract}

\section{Introduction}

Noncommunicable diseases (NCDs) are a major and increasing global health issue. According to the Global Burden of Diseases (GDB) 2015 report, there are between 39.8 and 40.5 million deaths per year from the four main categories of NCDs, namely cardiovascular diseases, diabetes, cancer, and chronic respiratory diseases (CRDs), representing 63\% of all global deaths. ${ }^{1}$ Of these, 3.9 million were due to CRDs. In 2008, the World Health Organization (WHO) estimated that over the following decade respiratory diseases would be responsible for the largest increase in global mortality. ${ }^{2,3}$ Low- and middle-income countries (LMICs) shoulder 80\% of the deaths from NCDs, of which an estimated $12 \%$ are due to respiratory problems, particularly asthma and chronic obstructive pulmonary disease (COPD). ${ }^{1,2}$ Respiratory diseases also have a significant economic impact, causing $4.7 \%$ of global disability-adjusted life-years (DALYs), twothirds of which are due to COPD and one-fifth due to asthma. ${ }^{1}$

The impact of CRDs in the developing world is a growing problem. COPD jumped from the fourth to the third most common cause of death between 1990 and 2010.4-6 Ninety per cent of COPD deaths now occur in LMICs. ${ }^{7-10}$ However, in many of these countries, governments and medical professionals have not historically given CRDs the attention they deserve. We set out to review the literature on the epidemiology of CRDs in sub-Saharan Africa (SSA), the Middle East and North Africa (MENA) with a focus on asthma and COPD.

\section{COPD}

The Global Initiative for Chronic Obstructive Lung Disease (GOLD), established in 1998, standardised the definition of COPD as a "preventable and treatable disease categorised by persistent airflow limitations which is mostly increasingly related and enhanced by chronic inflammatory responses of the airways and lung to harmful elements or smokes". Despite this, varying definitions of COPD are used globally. ${ }^{11}$ The ATS and ERS define COPD as a "preventable and treatable disease state characterised by airflow limitation that is not fully reversible" ${ }^{12}$ COPD is mainly caused by cigarette smoking and leads to symptoms of cough, excessive sputum production, and breathlessness, causing considerable disability as the illness progresses ${ }^{13}$ GOLD requires COPD diagnosis to be dependent on spirometry and specifically the documentation of a post-bronchodilator 'forced expiratory volume in one second' (FEV1) to 'forced vital capacity' (FVC) ratio (FEV1/FVC) of $<0.7$.

\section{Asthma}

The Global Initiative for Asthma (GINA) defines asthma as "heterogeneous disease, usually characterised by chronic airway inflammation. Its defined by the history of respiratory symptoms such as wheeze, shortness of breath, chest tightness and cough that vary over time and intensity, together with expiratory airflow limitation". ${ }^{14}$ However, asthma lacks a gold standard definition with other definitions also in use. Nevertheless, bronchial hyper-responsiveness, airway inflammation, and obstruction which may be reduced spontaneously or with medication are widely accepted features. ${ }^{15}$ There can be a chronic reduction in FEV1 and peak expiratory flow $(\mathrm{PEF})$, with the degree of reduction being one marker of disease severity. ${ }^{16}$

\section{Disease management and global initiatives}

Several guidelines, such as GOLD, GINA, and the 'Allergic Rhinitis and its Impact on Asthma' (ARIA) guidelines were developed to improve the management of CRDs. 


\section{CRDs}

In 2002, the WHO developed 'The Global Strategy for the Prevention and Control of NCDs'. Clear objectives were drawn to provide better surveillance and monitor CRD trends, and lower the level of exposure to recognised risk factors. Moreover, it aimed to strengthen the available health care systems. ${ }^{17}$ In addition to general guidelines for CRDs, asthma and COPD action plans for 2013 up to 2020 were developed to follow the WHO treatment guidelines, and provide influenza vaccination for patients with COPD., ${ }^{3,18}$ In 2002 and 2003, the WHO conducted the World Health Survey as a standardised survey tool measure to allow comparability of diseases findings, including asthma within and between countries to inform policy in a wide range of countries. ${ }^{19,20}$

\section{COPD}

In 1998, GOLD was initiated to produce recommendations for management of COPD based on best evidence and was last updated in January $2014 .{ }^{21-23,24}$ These guidelines stated that the use of spirometry is mandatory to diagnose COPD. 5,21,22,24 Other guidelines for COPD definition and diagnosis have been developed including the European Respiratory Society (ERS) and ATS. ${ }^{25,26}$ In 2015, the ERS/ATS published an official statement of update comparing the recognised COPD diagnostic standards and recommended further study to evaluate the long-term prognosis of patients diagnosed based on different COPD definitions. ${ }^{12}$ The BOLD initiative was established to further develop standardised methods for estimating COPD prevalence and associated risk factors in the 40 years and above population. ${ }^{27,28}$ In addition, it aims to measure its influence on quality of life, activity limitation, respiratory symptoms, and usage of healthcare services. ${ }^{28,29}$ BOLD studies have provided a solid base for assessing the economic burden of COPD by developing the $\mathrm{BOLD}$ Health Economic Model ${ }^{27,29}$ and the distribution of the disease in relation to age, sex, and smoking status across a range of countries and settings. ${ }^{28,30}$

\section{Asthma}

In the 1990s, GINA proposed strategies and guidelines for asthma management, and standardised the definition so it can be clearly distinguished from other respiratory diseases. ${ }^{31}$ In 1996, the International Union Against Tuberculosis and Lung Disease adopted these guidelines to control asthma in developing countries. ${ }^{32}$ However, as demonstrated by Ait-Khaled et al., there is a need to effectively utilise these guidelines especially in rural areas in Africa. ${ }^{33}$

\section{COPD and asthma disease burden}

WHO estimates that COPD affects almost 329 million people ( $4.8 \%$ of the world's population), however it is underrecognised and undertreated in most populations. ${ }^{34}$ Asthma is estimated to affect 334 million people, $4.9 \%$ of the world's population. 635 million people are reported to be living with some level of asthma-like symptoms. ${ }^{19}$

Worldwide, males and females are affected by COPD to a similar extent $\left(4.9 \%\right.$ and $4.7 \%$, respectively). ${ }^{35}$ The gender distribution of asthma varies with age; in childhood males are more frequently affected, however after adolescence the prevalence is higher among females. ${ }^{36}$ Overall asthma is estimated to affect slightly more females than males $(5.1 \%$ and $4.6 \%$, respectively). ${ }^{35}$

WHO estimates that 65 million people have moderate to severe COPD and three million people die as a direct cause http://dx.doi.org/10.4314/mmj.v29i2.24 of it annually. This corresponds to 5\% of all global deaths, the majority of which occur in LMICs. Deaths from COPD are on an upward trajectory. ${ }^{37,38}$ The number of affected individuals with asthma is predicted to increase to 400 million by $2025 .{ }^{19,39}$

In Africa, mortality from COPD was estimated to be 18.1 per 100,000 in 2001 with a similar rate, 18.3 per 100,000, seen in East Mediterranean countries. ${ }^{26}$ While deaths are less commonly seen in asthma than COPD, WHO estimates that there are 250,000 deaths per year from asthma, mainly in LMICs. ${ }^{40}$ Asthma is in the top twenty causes of disability in children globally. ${ }^{33}$

\section{COPD burden in SSA}

The burden of COPD in SSA is disputed and reports offer variable prevalence estimates. ${ }^{41,42}$ Finney et al. conducted a systematic review of nine cross-sectional studies (five from South Africa, two from Nigeria, one from Malawi, and one from Cape Verde) reporting a prevalence ranging from $4 \cdot 1 \%$ to $24 \cdot 8 \%$, based on the diagnostic method used. ${ }^{43}$ Chan-Yeung et al. estimate a prevalence of 179 per 100,000 in Africa and 301 per 100,000 in Eastern Mediterranean countries, less than that of America and Europe ${ }^{7,44}$ However, a recent systematic analysis by Adeolaye et al. reported the estimated median prevalence of COPD in persons aged 40 years or older as $13.4 \%$ (range $9 \cdot 4 \%$ to $22 \cdot 1 \%$ ), translating into 26.3 million (18.5 to 43.4 million) cases of COPD in SSA..$^{45}$ Within the SSA region, Cape Town in South Africa had the highest prevalence estimates published within the international BOLD study, as GOLD stage II prevalence was $22.2 \%$ in men above 40 years. ${ }^{46-48}$

There are several possible explanations for the variation in COPD prevalence estimates. Firstly, relevant epidemiological data is lacking because of a paucity of data from population representative samples. ${ }^{27}$ Secondly, the studies that do exist are limited by the lack of a standardised definition of COPD with marked variation in the diagnostic methods used. ${ }^{33}$ In particular, there is a widespread shortage of good quality post-bronchodilator spirometry. ${ }^{41,49}$ Diagnosis frequently depends on clinical judgment, and knowledge about COPD is often limited. Many people, including health workers, are not well informed about the effects of cigarette smoking and smoke from the burning of biomass fuels on their respiratory health. ${ }^{50}$

\section{Asthma burden in SSA}

There is a similar wide variation in reported asthma prevalence in Africa. Available published data gives estimates of asthma prevalence in sub-Saharan Africa between 6 and 20\%. ${ }^{51}$ The International Study of Asthma and Allergies in Childhood (ISAAC) has been the most widely used prevalence research methodology in Africa, ${ }^{40}$ where its diagnostic criteria have been shown to be reproducible, and able to discriminate children with allergic diseases in different areas of the world..$^{52}$ Another review reported that prevalence rates in Africa varied according to the ISSAC study results (Ethiopia 9.1\%, Kenya $15.8 \%$, Nigeria $13.0 \%$, and South Africa 20.3\%) while rural areas reported lower prevalence than urban areas. ${ }^{7,53}$ In 2011, Musafiri et al. reported an increase in asthma prevalence in Africa over the past two decades, with 50 million people currently living with asthma. ${ }^{54}$ In 2013, a systematic review by Adeloye et al. reported a similar prevalence to that of high-income countries. In 1997, the aggregated prevalence was highest in South Africa (53\% of 5-12 year olds) and lowest in The Gambia (1.9\% of $>15$ years). ${ }^{33}$ Adeloye et Malawi Med J. 2017 Jun;29(2):203-211 
al. estimated asthma increased in prevalence from $11.7 \%$ in 1990 to $12.8 \%$ in 2010 in the general population. This rise is further supported by the Global Burden of Asthma Report, which corroborates the highest levels being in South Africa. ${ }^{16}$ ISAAC phase three reported that Africa, the Indian sub-continent, and East Mediterranean had the highest proportion of severe asthmatics. ${ }^{55}$

\section{COPD burden in MENA countries}

As in SSA, the burden of COPD is increasing in MENA countries. Although there is a paucity of good epidemiological data, there appears to be substantial differences in prevalence estimations between countries in the region. ${ }^{44,49}$ Tunisia reportedly has a prevalence of $3.8 \%$ compared to 125 per 100,000 people in Algeria and 5.6\% in Lebanon. ${ }^{44} \mathrm{~A}$ recent study from Saudi Arabia estimated COPD prevalence to be $2.4 \%$ in the general population and $14.2 \%$ among smokers (56). United Arab Emirates reports a prevalence of $3.7 \%$ in 40 to 80 year olds in Abu Dhabi. ${ }^{57}$ The BREATHE study, a large observational population-based survey, completed in ten countries in MENA, and Pakistan, reports that the available data from the region does not represent national COPD prevalence accurately as there are infrequent community-based prevalence surveys in the region and available epidemiological data are either incomplete or restricted to small region. ${ }^{44,49,58}$ The estimated overall COPD adjusted prevalence according to symptoms or diagnosis and 10-pack/year smoking was 3.6\%, and is higher in men than in women $(5.2 \% \text { and } 1.8 \% \text {, respectively })^{58}$

\section{Asthma burden in MENA countries}

There is substantial variability in the reported prevalence of asthma in the MENA region. In 1998 the ISAAC study reported an overall prevalence of $16.5 \%$ in North Africa and $10.7 \%$ in the East Mediterranean. ${ }^{44}$ The study showed prevalence in children between $5 \%-12 \%$ in rural and urban Sudan, respectively, ${ }^{59}$ and ranging from $8.8 \%$ to $9.5 \%$ in rural and urban Jordan. ${ }^{44}$ The World Health Survey published the global asthma prevalence from 70 countries in 2012. The overall prevalence in the East Mediterranean region was $2.9 \%, 3.0 \%$, and $7.9 \%$ for 'doctor diagnosed', 'clinical', and 'wheezing symptoms asthma', respectively. ${ }^{19}$ In contrast the 'Asthma Insights and Reality in the Maghreb' (AIRMAG) study reported an overall prevalence of $3.6 \%$ in the general population of Maghreb, with no significant disparity between the three countries (Algeria, Morocco, and Tunisia). ${ }^{44,60,61}$ Egypt reported a prevalence of $14.7 \%$ for wheezing in that year and $9.4 \%$ of physician-diagnosed asthma. ${ }^{62}$ There was a varying prevalence in Saudi Arabia ranging from 8\% to $25 \%$ in children, with $19.6 \%$ of adolescents having doctor diagnosed asthma $a^{63}$ and $4.1 \%$ of adults self-reporting asthma. ${ }^{64}$ Iran also reported a similarly varying prevalence ranging from $1.4 \%$ to $5.9 \%$ in the adult population. ${ }^{65}$

\section{Risk factors for CRD in SSA and MENA}

There are several common environmental risk factors for CRD including; tobacco smoking, household and outdoor air pollution, and exposure to dust, gases, or fumes in occupational settings. ${ }^{36}$ Genetic factors are also implicated; this is beyond the scope of this review. It has, however, been recently acknowledged that for both asthma and COPD burden in LMICs, other causes are also contributing, particularly tuberculosis (TB), HIV and rapid urbanisation.

\section{Tobacco}

Tobacco smoking, alongside the aging of the population, are widely regarded as the most important risk factors for COPD globally. ${ }^{45,30,27}$ The WHO reports that smoking alone causes about $42 \%$ of CRD ${ }^{67}$ Environmental tobacco smoke exposure is a risk factor for asthma in paediatric patients. ${ }^{14}$ The rapid increase in smoking rates in LMICs reflecting the 'success' of intensive efforts by the Tobacco Industry to expand African markets will see the global prevalence of COPD increasing over coming decades. ${ }^{54,30,68,69}$

The burden of tobacco use in African countries is estimated to be between 8 and $43 \%$ for men and between 5 and $30 \%$ for women. ${ }^{54} \mathrm{COPD}$ prevalence in current smokers in men ranges from $9.4 \%$ to $56.9 \%$, with comparable broad ranges seen in other risk factors such as history of tuberculosis, exposure to biomass smoke, or occupational fumes. ${ }^{42,70}$ Smoking is also increasing in the MENA region. An epidemiological study in Turkey reported that COPD prevalence in current male smokers above 40 years of age was $18.1 \%$, and $4.5 \%$ amongst younger smokers; $25.5 \%$ of the women and $57.2 \%$ of the men were current smokers. The rate of smoking varies greatly within the region, from $20 \%$ of men in Iran to $63 \%$ in Turkey. ${ }^{44}$ The Burden of Obstructive Lung Disease (BOLD) study analysed COPD prevalence and mortality in association with smoking and poverty, and reports that tobacco and exposure to environmental tobacco smoke remain the greatest risk factors for airflow obstruction. ${ }^{5}$ However, many areas with high COPD mortality rates have a low consumption of tobacco. ${ }^{5,34}$ Tobacco alone, therefore, does not fully illuminate the varying prevalence globally, and other factors need to be explored in LMICs. ${ }^{5,42,50,30,71}$

\section{Household air pollution}

Exposure to household air pollution from biomass fuel smoke is a recognised risk factor for CRD, particularly COPD and mostly among women. ${ }^{72,73}$ Biomass fuel contains material from plants or animals burnt by humans such as wood, animal dung, crop residues, and grass. ${ }^{7}$ It is estimated that over $80 \%$ of homes in sub-Saharan Africa and $90 \%$ of rural houses use biomass fue. ${ }^{17,71}$ A Malawian study, found women and people of lower socioeconomic status in SSA are particularly affected by biomass smoke exposure. ${ }^{74}$ In MENA countries, household air pollution from biomass fuel smoke is also considered a factor for CRD but to a lesser extent. $^{26,49}$ The link between asthma and biomass exposure is less clear $^{75,76}$; however, a recent systematic review reported a relationship between these fuels and asthma symptoms. ${ }^{77}$ In the MENA region, 25 to $45 \%$ of patients with COPD were known to have been exposed to biomass fuel and were reported non-smokers. ${ }^{44}$ Ben Abdallah et al. estimates 54.5\% of female patients in turkey's study with COPD in rural areas were exposed to biomass. The same study reports, however, that the relative risk from smoking was 3.4 times greater than biomass exposure and 3.3 times greater than occupational exposure. ${ }^{44,78}$

\section{Outdoor air pollution}

Outdoor air pollution is variable, differing greatly between urban and rural environments and with the degree and nature of local industry. The main contributors to the outdoor air pollution are combination of wood smoke and vehicle exhausts ${ }^{79}$ with higher levels of nitrogen dioxide, ozone, particulate matter and sulphur dioxide in urban areas. ${ }^{80}$ There has been a rise in the prevalence of asthma that corresponds with increasing urbanisation over the last 
three decades ${ }^{81}$ There is evidence that high levels of vehicle emissions and living in the urban environment is correlated with the rising trend in allergic respiratory diseases. ${ }^{80}$ Air pollution has a quantifiable impact on COPD mortality and morbidity and is also recognised to have a negative influence on lung development in children. ${ }^{38,82}$ Research on outdoor air pollution and CRD in SSA and MENA regions is limited, and the majority of the data in these regions is extrapolated from studies observing other risk factors.

The global population in urban areas is predicted to increase from $45 \%$ to $59 \%$ by 2025 . Africa's urban population in particular is growing rapidly and predicted to increase from $40 \%$ to $56 \%$ by 2050 . The impact of air pollution on CRD can therefore also be expected to increase. ${ }^{83}$ Studies looking at wheezing, asthma, and COPD in Africa illustrate ruralurban gradients, with generally low levels in the villages and increasing prevalence with urbanization. ${ }^{7,84}$

\section{Occupational exposures}

There is little evidence regarding the burden of asthma due to occupational exposure in LMICS, in particular Africa outside South Africa. ${ }^{85}$ Hoy et al. estimates 15 to $20 \%$ of asthma cases are caused by occupational exposure. However, this is only valid to developed countries which have strong occupational health data. ${ }^{85}$ Similarly, the American Thoracic Society (ATS) reported occupational exposure as the main cause of $15 \%$ of COPD and asthma and was associated with an increased mortality rate in the COPD population. ${ }^{86}$ GINA also reported that occupational exposure can trigger asthma in 5 to $20 \%$ of adults. ${ }^{31}$ These findings have been replicated by a study in a 'never-smoked population' in two industrialised areas of Sweden, where $24 \%$ of the study population was found to have relevant occupational exposure. ${ }^{4}$ A Nigerian study reported a high prevalence of occupational asthma $(6.5 \%)$ and rhinitis $(78 \%)$ in woodworkers, which increased with duration of employment. ${ }^{87}$ As reported by Finney et al., COPD was prevalent in $13.4 \%$ of South African gold miners and $33.1 \%$ of Nigerian shoe factory workers. ${ }^{43}$

In the MENA region, there are variable reports regarding occupational exposure. A study from Sudan reported that $26 \%$ of miners had symptoms of chronic bronchitis and mine dust as the leading cause. ${ }^{88,89}$ The non-smoker BOLD study in Tunisia reported $92 \%$ of those exposed to occupational pollutants suffered from chronic bronchitis and a significant association (OR 1.87, 95\%CI 1.14 - 12.86) between occupational exposure and COPD as well as having more respiratory symptoms. ${ }^{90}$ This is further evidenced by a recent study in Dubai which showed a significant association between occupational exposure to dust and airflow limitation (OR 2.07, 95\% CI 1.20 - 3.59)..$^{91}$

\section{Pulmonary tuberculosis (TB)}

According to the WHO stop TB partnership, there are more than 2.4 billion people infected with TB globally and 9.6 million new cases are diagnosed every year, with the majority occurring in LMICs. TB is known to cause inflammation of the airways and changes characteristic of COPD. TB patients often have airflow obstruction; studies have found a prevalence varying from $28 \%$ to $68 \% .{ }^{92,93}$ A large study based in South Africa in 2004 reported that the strongest predictor of COPD was previous TB (OR 4.9, 95\% CI 2.6 - 9.2) in men and (OR 6.6, 95\% CI 3.7 - 11.9) in women, an association stronger than both smoking and biomass exposure. ${ }^{94}$

The ISAAC study found an inverse relationship between asthma symptom prevalence and estimated TB incidence. ${ }^{95}$ It has been hypothesized that exposure to mycobacterium tuberculosis may reduce the risk of developing asthma through the induction of a Th1-like immune response..$^{52}$ Research is however lacking and this requires more study.

\section{HIV}

The link between HIV and chronic respiratory disease is unclear, however in both children and adults, HIV patients are reported to have a higher risk of respiratory disease. ${ }^{96,97}$ Countries with a high reported prevalence of HIV also have high reported prevalence of asthma ${ }^{7}$ and children with HIV on anti-retroviral therapy have more recurrent wheeze. ${ }^{96}$ Similarly, a study in Cameroon reported a positive association between COPD and HIV infection (OR 2.85, CI 1.20-6.74, $\mathrm{p}=0.017)$. This study found a COPD prevalence of $2.2 \%$ in HIV positive patients compared to $0.7 \%$ in HIV negative participants. It did, however, note the main determinants of COPD to be TB, weight and chronic respiratory symptoms. ${ }^{66}$ Similar studies in South Africa and Nigeria have also found an association between HIV and airflow obstruction. ${ }^{96}$ The pathophysiology of the link between obstructive lung disease and HIV is not understood but thought to involve the development of lung inflammation and a low lung diffusing capacity. ${ }^{97} \mathrm{~A}$ rapid decline in lung function, obliterative bronchiolitis and severe airflow limitation in children with HIV has also been reported. ${ }^{96}$

\section{Socioeconomic status}

Poor socioeconomic status is an independent risk factor for COPD and there is a significant correlation with lung function even after adjustment for smoking, occupational exposure and ethnicity. ${ }^{71,98}$ The interplay of several risk factors is complex but thought to include low birth weight, recurrent respiratory infections, poor nutrition, housing conditions and air pollution..$^{99}$ A similar pattern of exposure to risk factors and an impact on health care access may also influence the development of asthma. A study by Pallasaho et al. in Finland, Sweden and Estonia interviewed 44,483 participants and reported a significant link between low socio-economic status and asthma-like symptoms. ${ }^{100}$ These issues need to be further explored in SSA and MENA.

\section{Chronic asthma}

Chronic airway inflammation and obstruction from uncontrolled asthma has been hypothesized as a cause of lung re-modelling, leading to fibrosis and the irreversible airflow obstruction of COPD. ${ }^{15}$ Globally the increasing prevalence and on going lack of access to effective treatment (such as inhaled corticosteroids) will likely be contributing to the development of COPD in asthma patients.

\section{Other risk factors that have been implicated globally for asthma}

\section{Allergen inhalation}

Indoor allergens such as house dust, cockroach and hairy pets can sensitize asthmatic patients and are considered important risk factors for the emergence of the disease in SSA. ${ }^{101,89}$ The risk of developing asthma is higher in children that in adults. ${ }^{101}$ In polluted urban areas, the prevalence of allergic respiratory diseases could be increased by exposure to inhaled allergens, which foster the airway sensitization and cause a more severe immunoglobulin arbitrated reaction to further aeroallergens and airway inflammation. ${ }^{82}$ A rapid asthmatic reaction can be triggered by allergen inhalation. These create immunoglobulin mediated mast 
cell degranulation and downstream inflammation and also a late asthmatic reaction, including activation of T-helper 2 lymphocytes. ${ }^{102}$ In many African countries, asthma and allergic sensitization are becoming more widespread, a trend supported by studies in Ghana, Kenya, Ethiopia and Rwanda. This rising tendency is mostly associated to sensitization to house dust mite, tobacco smoking, and living in urbanised areas. ${ }^{103}$ Other specific allergic sensitizers in Africa are span trees, grasses, and weeds as well as airborne mould spores. In MENA countries, increased asthma prevalence has been shown to be associated with increased rates of sandstorms. ${ }^{103}$

\section{Infections}

In SSA, the incidence of acute respiratory infections is one of the highest in the world. Household air pollution is considered to be a risk factor for acute respiratory tract infections in children, which in turn may increase the risk of asthma. ${ }^{26}$ Several viral infections can progress to asthma in children by causing wheezy bronchitis. ${ }^{102}$ Children who experience severe respiratory infections in early childhood have up to a $50 \%$ risk of developing asthma in subsequent years of childhood and COPD in future life. ${ }^{101,104}$

Other important factors implicated in asthma include drugs, exercise and diet. In particular cow's milk, egg, nuts, fish, and shellfish are the most allergenic foods, causing an IgEmediated reaction. ${ }^{101,102}$ About $40 \%$ of allergic children have asthma and 30\% will have allergic rhinitis. ${ }^{101}$ Food induced asthma appears to be less frequent in SSA than in the developed world although data are limited. ${ }^{102}$ In a Zimbabwean study, tropical dietary lifestyles considered a probable cause of allergen sensitization in Africa included grains, plants, fruits and even insects. ${ }^{103}$

\section{Conclusions}

CRD is a very real present and growing problem across SSA and the MENA region. There is, however, limited epidemiological evidence currently representing an important gap in the evidence base and need for further research. Across both regions, asthma and COPD are likely to be under-estimated, under-diagnosed, under-treated as well as inadequately prevented. ${ }^{7,51,105}$ Although there have been many global strategies for management and control put forward, the implementation of these guidelines is limited and is logistically challenging, especially in LMICs. In these areas, which are facing threats from the tobacco epidemic, household and outdoor air pollution and urbanisation, there is often limited adoption of international guidelines within resource-limited health systems. There are important challenges regarding the lack of diagnostic equipment, treatment and trained and experienced health care providers which need to be addressed through strengthening of health systems. ${ }^{89,106}$

\section{Competing interests}

All authors declare that they have no competing interests related to this work.

\section{References}

1. Wang H, Naghavi M, Allen C, Barber RM, Bhutta ZA, Carter A, et al. Global, regional, and national life expectancy, all-cause mortality, and cause-specific mortality for 249 causes of death, 1980-2015: a systematic analysis for the Global Burden of Disease Study 2015. Lancet [Internet]. Elsevier; 2016 Oct 30;388(10053):1459-544. Available from: http://dx.doi.org/10.1016/S0140-6736(16)31012-1

2. de-Graft Aikins A, Unwin N, Agyemang C, Allotey P, Campbell C,
Arhinful D. Tackling Africa's chronic disease burden: from the local to the global. Global Health [Internet]. 2010;6(August 2016):5. Available from: http://www.pubmedcentral.nih.gov/articlerender.fcgi?artid=2873 934\& tool=pmcentrez\&rendertype $=$ abstract

3. World Health Organization. Global action plan for the prevention and control of noncommunicable diseases 2013-2020. World Heal Organ [Internet]. 2013;102. Available from: http://apps.who.int/iris/ bitstream/10665/94384/1/9789241506236_eng.pdf

4. Hagstad S, Backman H, Bjerg A, Ekerljung L, Ye X, Hedman L, et al. Prevalence and risk factors of COPD among never-smokers in two areas of Sweden - occupational exposure to gas, dust or fumes is an important risk factor. Respir Med [Internet]. 2015; Available from: http://linkinghub.elsevier.com/retrieve/pii/S0954611115300597

5. Burney P, Jithoo A, Kato B, Janson C, Mannino D, NizankowskaMogilnicka E, et al. Chronic obstructive pulmonary disease mortality and prevalence: the associations with smoking and poverty--a BOLD analysis. Thorax [Internet]. 2014;69(5):465-73. Available from: http:// www.pubmedcentral.nih.gov/articlerender.fcgi? artid $=3995258 \&$ tool $=p$ mcentrez\&rendertype $=$ abstract

6. Mohsen N, Haidong W, Rafael L, Adrian D, Xiaofeng L, Maigeng $\mathrm{Z}$, et al. Global, regional, and national age-sex specific all-cause and cause-specific mortality for 240 causes of death, 1990-2013: a systematic analysis for the Global Burden of Disease Study 2013. Lancet (London, England) [Internet]. Elsevier; 2015 Jan 10 [cited 2014 Dec 19];385(9963):117-71. Available from: http://www.thelancet.com/ article/S0140673614616822/fulltext

7. van Gemert F, van der Molen T, Jones R, Chavannes N. The impact of asthma and COPD in sub-Saharan Africa. Primary Care Respiratory Journal. 2011. p. 240-8.

8. El Hasnaoui A, Rashid N, Lahlou A, Salhi H, Doble A, Nejjari C. Chronic obstructive pulmonary disease in the adult population within the Middle East and North Africa region: rationale and design of the BREATHE study. Respir Med [Internet]. Elsevier Ltd; 2012;106:S315. Available from: http://linkinghub.elsevier.com/retrieve/pii/ S0954611112700100

9. Anderson ES, Mónica O, Dan C, Jeremy AL. Cost effectiveness of strategies to combat road traffic injuries in sub-Saharan Africa and South East Asia: mathematical modelling study. Bmj. 2012;344(mar02 1):e612-e612.

10. Khan MA, Ahmed M, Anil S, Walley J. Strengthening the delivery of asthma and chronic obstructive pulmonary disease care at primary health-care facilities: Study design of a cluster randomized controlled trial in Pakistan. Glob Health Action. 2015;8(1):1-8.

11. Lopez AD, Mathers CD. Measuring the global burden of disease and epidemiological transitions: 2002-2030. Ann Trop Med Parasitol [Internet]. 2006;100(5-6):481-99. Available from: https://www.unihohenheim.de/fileadmin/einrichtungen/hcecon/Dateien_und_Bilder/ Dateien/Gender_und_Gesundheit/SS_10/Lopez_Mathers_2006 Measuring_the_global_burden_of_disease_and_epidemiological_ transitions.pdf

12. Celli BR, Decramer M, Wedzicha J a., Wilson KC, Agustí A, Criner GJ, et al. An official American Thoracic Society/European Respiratory Society statement: research questions in COPD. Eur Respir J [Internet]. 2015 Apr;45(4):879-905. Available from: http://erj.ersjournals.com/ cgi/doi/10.1183/09031936.00009015

13. McLean S, Barbour V, Wild S, Simpson C, Sheikh A. Models for estimating projections for disease prevalence and burden: a systematic review focusing on chronic obstructive pulmonary disease. J Health Serv Res Policy [Internet]. 2015;22(2):1355819615579232. Available from: http://hsr.sagepub.com/content/early/2015/04/02/1355819615579232. full

14. Cazzoletti L, Marcon A, Corsico A, Janson C, Jarvis D, Pin I, et al. Asthma Severity According to Global Initiative for Asthma and Its Determinants: An International Study. Int Arch Allergy Immunol [Internet]. 2010;151(1):70-9. Available from: http://www.karger.com/ DOI/10.1159/000232572 
15. Silva GE, Sherrill DL, Guerra S, Barbee RA. Asthma as a risk factor for COPD in a longitudinal study. Chest [Internet]. The American College of Chest Physicians; 2004;126(1):59-65. Available from: http://dx.doi.org/10.1378/chest.126.1.59

16. Braman SS. The Global Burden of Asthma. Chest [Internet]. 2006 Jul;130(1, Supplement):4S-12S. Available from: http://www. sciencedirect.com/science/article/pii/S0012369215329524

17. World Health Organization. WHO strategy for prevention and control of chronic respiratory diseases [Internet]. Geneva: World Health Organization. 2002. Available from: http://www.who.int/respiratory/ publications/WHO_MNC_CRA_02.1.pdf

18. World Health Organization. Action Plan for the Global Strategy for the Prevention and Control of Noncommunicable Diseases The six objectives of the 2008-2013 [Internet]. Geneva: World Health Organization. 2008. Available from: http://whqlibdoc.who.int/ publications/2009/9789241597418_eng.pdf

19. To T, Stanojevic S, Moores G, Gershon AS, Bateman ED, Cruz AA, et al. Global asthma prevalence in adults: findings from the cross-sectional world health survey. BMC Public Health [Internet]. BioMed Central Ltd; 2012 Dec 19;12(1):204. Available from: http://bmcpublichealth biomedcentral.com/articles/10.1186/1471-2458-12-204

20. Sembajwe G, Cifuentes M, Tak SW, Kriebel D, Gore R, Punnett L. National income, self-reported wheezing and asthma diagnosis from the World Health Survey. Eur Respir J [Internet]. 2010 Feb 1;35(2):279-86. Available from: http://www.ncbi.nlm.nih.gov/pubmed/19741032

21. Pauwels R, Buist A. Global strategy for the diagnosis, management, and prevention of chronic obstructive pulmonary disease. Am J ... [Internet]. 2014;40-5. Available from: http://www.atsjournals.org/doi/ abs/10.1164/ajrccm.163.5.2101039

22. Rodríguez-Roisin R, Agustí A. Iniciativa GOLD 2011. ¿Cambio de paradigma? Arch Bronconeumol [Internet]. 2012 Aug;48(8):286-9. Available from: http://www.ncbi.nlm.nih.gov/pubmed/22537593

23. Barreiro E, Criner GJ. Update in chronic obstructive pulmonary disease 2013. Am J Respir Crit Care Med [Internet]. 2014;189(11):133744. Available from: http://www.atsjournals.org/doi/abs/10.1164/ rccm.201402-0245UP

24. Rabe KF, Hurd S, Anzueto A, Barnes PJ, Buist SA, Calverley P, et al. Global strategy for the diagnosis, management, and prevention of chronic obstructive pulmonary disease: GOLD executive summary. Am J Respir Crit Care Med [Internet]. 2007 Sep 15;176(6):532-55. Available from: http://www.goldcopd.org/.

25. Halbert RJ, Isonaka S, George D, Iqbal A. Interpreting COPD Prevalence Estimates. Chest [Internet]. 2003 May;123(5):1684-92. Available from: http://journal.publications.chestnet.org/article. aspx?articleid $=1081528$

26. Chan-Yeung M, Ait-Khaled N, White N, Ip MS, Tan WC. The burden and impact of COPD in Asia and Africa. Int J Tuberc Lung Dis [Internet]. 2004;8(1):2-14. Available from: http://ovidsp.ovid. com/ovidweb.cgi $\mathrm{T}=\mathrm{JS} \& \mathrm{PAGE}=$ reference $\& \mathrm{D}=\operatorname{med} 5 \& \mathrm{NEWS}=\mathrm{N} \&$ $\mathrm{AN}=14974740$

27. Buist a. S, Vollmer WM, McBurnie M a. Worldwide burden of COPD in high- and low-income countries. Part I. The Burden of Obstructive Lung Disease (BOLD) Initiative. Int J Tuberc Lung Dis. 2008;12(7):703-8.

28. Burden of Obstructive Lung Disease ( BOLD). Burden of Obstructive Lung Disease ( BOLD ) Chapter 1 Protocol. Burden of Obstructive Lung Disease ( Bold ). 2006. p. 1-17.

29. Rutten-van Mölken M. Raising the awareness: projecting the future burden of COPD with the BOLD model. Eur Respir J Off J Eur Soc Clin Respir Physiol [Internet]. 2009;34(4):787-9. Available from: http://www.ncbi.nlm.nih.gov/pubmed/19797666
30. Buist AS, McBurnie MA, Vollmer WM, Gillespie S, Burney P, Mannino DM, et al. International variation in the prevalence of COPD (The BOLD Study): a population-based prevalence study. Lancet [Internet]. Elsevier Ltd; 2007;370(9589):741-50. Available from: http://linkinghub.elsevier.com/retrieve/pii/S0140673607613774

31. Global Initiative for Asthma. Global Strategy for Asthma Mangment and prevention. 2015.

32. Aït-Khaled N, Enarson DA, Bencharif N, Boulahdib F, Camara LM, Dagli E, et al. Implementation of asthma guidelines in health centres of several developing countries. Int J Tuberc Lung Dis [Internet]. 2006 Jan;10(1):104-9. Available from: http://www.ncbi.nlm.nih.gov/ pubmed/16466046

33. Adeloye D, Chan KY, Rudan I, Campbell H. An estimate of asthma prevalence in Africa: a systematic analysis. Croat Med J [Internet]. 2013;54(6):519-31. Available from: http://www.pubmedcentral.nih. gov/articlerender.fcgi?artid $=3893990 \&$ tool $=$ pmcentrez\&rendertype $=a$ bstract

34. Allwood B, Van Zyl-Smit RN. Chronic obstructive pulmonary disease in South Africa: Under-recognised and undertreated. South African Med J [Internet]. 2015 Sep 15;105(9):785. Available from: http://www.samj.org.za/index.php/samj/article/view/9971

35. Bereza BG, Troelsgaard Nielsen A, Valgardsson S, Hemels ME, Einarson TR. Patient preferences in severe COPD and asthma: a comprehensive literature review. Int J Chron Obstruct Pulmon Dis [Internet]. 2015;10:739-44. Available from: http://www.pubmedcentral. nih.gov/articlerender.fcgi?artid=4399696\&tool=pmcentrez\&rendertyp $\mathrm{e}=$ abstract

36. Leynaert B, Sunyer J, Garcia-Esteban R, Svanes C, Jarvis D, Cerveri $\mathrm{I}$, et al. Gender differences in prevalence, diagnosis and incidence of allergic and non-allergic asthma: a population-based cohort. Thorax [Internet]. 2012;67(7):625-31. Available from: http://thorax.bmj.com/ content/67/7/625.full.pdf + html

37. Mannino DM, Buist AS. Global burden of COPD: risk factors, prevalence, and future trends. Lancet [Internet]. 2007;370(9589):76573. Available from: http://linkinghub.elsevier.com/retrieve/pii/ S0140673607613804

38. Liu Y, Lee K, Perez-Padilla R, Hudson NL, Mannino DM. Outdoor and indoor air pollution and COPD-related diseases in high- and lowincome countries. Int J Tuberc Lung Dis. 2008;12(2):115-27.

39. Anandan C, Nurmatov U, van Schayck OCP, Sheikh A. Is the prevalence of asthma declining? Systematic review of epidemiological studies. Allergy [Internet]. 2010 Feb;65(2):152-67. Available from: http://doi.wiley.com/10.1111/j.1398-9995.2009.02244.x

40. Bousquet J, Mantzouranis E, Cruz AA, Aït-Khaled N, BaenaCagnani CE, Bleecker ER, et al. Uniform definition of asthma severity, control, and exacerbations: Document presented for the World Health Organization Consultation on Severe Asthma. J Allergy Clin Immunol. 2010;126(5):926-38.

41. Salvi S. The silent epidemic of COPD in Africa. Lancet Glob Heal [Internet]. Salvi. Open Access article distributed under the terms of CC BY; 2015;3(1):e6-7. Available from: http://linkinghub.elsevier.com/ retrieve/pii/S2214109X14703596

42. Mannino DM. COPD in Africa: the coming storm. Int $J$ Tuberc Lung Dis [Internet]. 2013;17(5):572. Available from: http://www.ncbi. nlm.nih.gov/pubmed/23575320

43. Finney LJ, Feary JR, Leonardi-Bee J, Gordon SB, Mortimer K. Chronic obstructive pulmonary disease in sub-Saharan Africa: a systematic review [Review article]. Int J Tuberc Lung Dis [Internet]. 2013;17(5):583-9. Available from: http://www.ncbi.nlm.nih.gov/ pubmed/23394105

44. Ben Abdallah FC, Taktak S, Chtourou a, Mahouachi R, Kheder A Ben. Burden of Chronic Respiratory Diseases (CRD) in Middle East and North Africa (MENA). World Allergy Organ J [Internet]. 2011;4(1 Suppl):S6-8. Available from: http://www.pubmedcentral.nih.gov/ articlerender.fcgi? artid $=3666180 \&$ tool $=$ pmcentrez\&rendertype $=$ abstra ct 
45. Adeloye D, Basquill C, Papana A, Chan KY, Rudan I, Campbell H. An Estimate of the Prevalence of COPD in Africa: A Systematic Analysis. COPD [Internet]. 2014; Available from: http://www.ncbi. nlm.nih.gov/pubmed/24946179

46. Allwood B, Gillespie R, Bateman M, Olckers H, Taborda-Barata $\mathrm{L}$, Calligaro $\mathrm{G}$, et al. The burden of obstructive lung disease (BOLD) methodology overestimates the prevalence of COPD: A 5-year followup study. Eur Respir J [Internet]. 2014 Dec 23;44(Suppl 58). Available from: http://erj.ersjournals.com/content/44/Suppl_58/P1084.abstract

47. Gemert F Van, Molen T Van Der, Jones R, Chavannes N. The impact of asthma and COPD in sub-Saharan Africa. Prim Care Respir J. 2011;1-9.

48. Mannino DM, Buist AS. Global burden of COPD: risk factors, prevalence, and future trends. Lancet [Internet]. Elsevier Ltd 2007;370(9589):765-73. Available from: http://linkinghub.elsevier com/retrieve/pii/S0140673607613804

49. Martins P, Rosado-Pinto J, do Céu Teixeira M, Neuparth N, Silva O, Tavares $\mathrm{H}$, et al. Under-report and underdiagnosis of chronic respiratory diseases in an African country. Allergy [Internet]. 2009;64(7):1061-7. Available from: http://www.ncbi.nlm.nih.gov/pubmed/19210360

50. van Gemert F, Kirenga B, Chavannes N, Kamya M, Luzige S, Musinguzi $\mathrm{P}$, et al. Prevalence of chronic obstructive pulmonary disease and associated risk factors in Uganda (FRESH AIR Uganda) a prospective cross-sectional observational study. Lancet Glob Heal [Internet]. van Gemert et al. Open Access article distributed under the terms of CC BY; 2015;3(1):e44-51. Available from: http://linkinghub. elsevier.com/retrieve/pii/S2214109X14703377

51. Jumbe Marsden E, Wa Somwe S, Chabala C, Soriano JB, Vallès $\mathrm{CP}$, Anchochea J. Knowledge and perceptions of asthma in Zambia: A cross-sectional survey. BMC Pulm Med [Internet]. BMC Pulmonary Medicine; 2016;16(1):1-8. Available from: http://www.embase.com/ search/results? subaction $=$ viewrecord $\&$ from $=$ export\&id $=$ L 6082532 05\%5Cnhttp://dx.doi.org/10.1186/s12890-016-0195-3\%5Cnhttp:// findit.library.jhu.edu/resolve? $\mathrm{sid}=$ EMBASE $\&$ issn $=14712466 \& \mathrm{id}=\mathrm{d}$ oi:10.1186/s12890-016-0195-3\&atitle=Knowledge+and+perc

52. Asher MI, Stewart AW, Mallol J, Montefort S, Lai CKW, Aït-Khaled $\mathrm{N}$, et al. Which population level environmental factors are associated with asthma, rhinoconjunctivitis and eczema? Review of the ecological analyses of ISAAC Phase One. Respir Res [Internet]. 2010;11:8. Available from: http://www.pubmedcentral.nih.gov/articlerender.fcgi? artid $=2831000 \&$ tool $=$ pmcentrez\&rendertype $=$ abstract

53. Lai C, Beasley R, Crane J, Foliaki S, Shah J, Weiland S. Global variation in the prevalence and severity of asthma symptoms: Phase Three of the International Study of Asthma and Allergies in Childhood (ISAAC). Thorax [Internet]. 2009 Feb 22; Available from: http:// thorax.bmj.com/content/early/2009/02/22/thx.2008.106609.abstract

54. Musafiri S, van Meerbeeck J, Musango L, Brusselle G, Joos G, Seminega B, et al. Prevalence of atopy, asthma and COPD in an urban and a rural area of an African country. Respir Med [Internet]. 2011;105(11):1596-605. Available from: http://linkinghub.elsevier. com/retrieve/pii/S0954611111002137

55. Christopher KWL, Richard B, Julian C, Sunia F, Jayant S. Global variation in the prevalence and severity of asthma symptoms: Phase Three of the International Study of Asthma and Allergies in Childhood (ISAAC). Thorax. 2014;(0):2-5.

56. Alsubaiei ME, Cafarella PA, Frith PA, Mcevoy RD, Effing TW. Current care services provided for patients with COPD in the Eastern province in Saudi Arabia : a descriptive study. Int J COPD. 2015;2379_ 91

57. Al Zaabi A, Asad F, Abdou J, Al Musaabi H, Al Saiari MB, Mohammed Buhussien AS, et al. Prevalence of COPD in Abu Dhabi, United Arab Emirates. Respir Med [Internet]. Elsevier Ltd; 2011;105(4):566-70. Available from: http://dx.doi.org/10.1016/j. rmed.2010.12.008
58. Tageldin MA, Nafti S, Khan JA, Nejjari C, Beji M, Mahboub B, et al. Distribution of COPD-related symptoms in the Middle East and North Africa: Results of the BREATHE study. Respir Med [Internet]. Elsevier Ltd; 2012;106:S25-32. Available from: http:/linkinghub. elsevier.com/retrieve/pii/S0954611112700124

59. Ibrahim SMH, Haroun HM, Ali HM, Eldeen I, Eldeen MT. Audit of acute asthma management at the Paediatric Emergency Department at Wad Madani Children' s Hospital, Sudan. Sudan J Paediatr. 2012;12(1):104-14.

60. Adeloye D, Chan KY, Rudan I, Campbell H. An estimate of asthma prevalence in Africa: a systematic analysis. Croat Med J [Internet]. 2013 Dec;54(6):519-31. Available from: http://www.ncbi.nlm.nih.gov/ pmc/articles/PMC3893990/

61. El Ftouh M, Yassine N, Benkheder A, Bouacha H, Nafti S, Taright S, et al. Paediatric asthma in North Africa: the Asthma Insights and Reality in the Maghreb (AIRMAG) study. Respir Med [Internet]. Elsevier Ltd; 2009;103(SUPPL. 2):S2-11. Available from: http://dx.doi.org/10.1016/ S0954-6111(09)70022-8

62. Salama A a, Mohammed A a, El Okda ESE, Said RM. Quality of care of Egyptian asthmatic children: clinicians adherence to asthma guidelines. Ital J Pediatr [Internet]. 2010;36:33. Available from: http:// ovidsp.ovid.com/ovidweb.cgi? T $=\mathrm{JS} \& \mathrm{PAGE}=$ reference $\& \mathrm{D}=$ medl\&NE $\mathrm{WS}=\mathrm{N} \& \mathrm{AN}=20406498$

63. Al-Moamary M, Alhaider S, Idrees M, Al Ghobain M, Zeitouni M, Al-Harbi A, et al. The Saudi Initiative for Asthma - 2016 update: Guidelines for the diagnosis and management of asthma in adults and children [Internet]. Annals of Thoracic Medicine. 2016. p. 3. Available from: http://www.pubmedcentral.nih.gov/articlerender.fcgi?artid= $3506098 \&$ tool $=$ pmcentrez\&rendertype $=$ abstract $\% 5 \mathrm{Cnhttp}: / / \mathrm{www}$. thoracicmedicine.org/text.asp?2016/11/1/3/173196

64. Moradi-Lakeh M, El Bcheraoui C, Daoud F, Tuffaha M, Kravitz H, Al Saeedi M, et al. Prevalence of asthma in Saudi adults: findings from a national household survey, 2013. [Internet]. BMC pulmonary medicine. 2015. p. 77. Available from: http://www.pubmedcentral.nih. gov/articlerender.fcgi? artid $=4517561 \&$ tool $=$ pmcentrez\&rendertype $=\mathrm{a}$ bstract

65. Mohammadi M, Parsi B. Prevalence of Asthma and Respiratory Symptoms among University Students in Sari ( North of Iran ). Natl Res Inst Tuberc Lung Dis. 2016;15(1):1-8.

66. Pefura-Yone EW, Fodjeu G, kengne AP, Roche N, Kuaban C. Prevalence and determinants of chronic obstructive pulmonary disease in HIV infected patients in an African country with low level of tobacco smoking. Respir Med [Internet]. 2015;109(2):247-54. Available from: http://linkinghub.elsevier.com/retrieve/pii/S0954611114004223

67. Stevens G. Global Health Risks: Mortality and burden of disease attributable to selected major risks. Bull World Health Organ [Internet]. 2009;87:646-646. Available from: http://www.who.int/healthinfo/ global_burden_disease/GlobalHealthRisks_report_full.pdf

68. Sandelowsky H, Ställberg B, Nager A, Hasselström J. The prevalence of undiagnosed chronic obstructive pulmonary disease in a primary care population with respiratory tract infections - a case finding study. BMC Fam Pract [Internet]. BioMed Central Ltd; 2011;12(1):122. Available from: http://www.biomedcentral.com/1471-2296/12/122

69. C. P, W. C, N. P, S. P, N. C, J. I. Acomparative study of COPD burden between urban vs rural communities in northern Thailand. Int J COPD [Internet]. 2015;10(2 June 2015):1035-42. Available from: http://www.embase.com/search/results?subaction=viewrecord\&fro $\mathrm{m}=$ export\&id=L604984143\%5Cnhttp://dx.doi.org/10.2147/COPD. S82303\%5Cnhttp://rd8hp6du2b.search.serialssolutions.com?sid=EMB ASE\&issn $=11782005 \&$ id $=$ doi: $10.2147 \% 2$ FCOPD.S82303\&atitle $=$ Ac omparative + study + of $+\mathrm{CO}$

70. Finney LJ, Feary JR, Leonardi-Bee J, Gordon SB, Mortimer K. Chronic obstructive pulmonary disease in sub-Saharan Africa: a systematic review. Int J Tuberc Lung Dis [Internet]. 2013 May 1;17(5):583-9. Available from: http://www.ncbi.nlm.nih.gov/ pubmed/23394105 
71. Sundeep S S, Peter J B. Chronic obstructive pulmonary diseasein nonsmokers. Lancet [Internet]. Elsevier Ltd; 2009 Dec;374(9706):1964-5. Available from: http://www.ncbi.nlm.nih.gov/pubmed/20006126

72. Ko FW, Hui DS, Lai CK. Worldwide burden of COPD in highand low-income countries. Part III. Asia-Pacific studies. Int J Tuberc Lung Dis [Internet]. 2008;12(7):713-7. Available from: http:/ docstore.ingenta.com/cgi-bin/ds_deliver/1/u/d/ISIS/64266504.1/iuatld/ ijtld/2008/00000012/00000007/art00005/4B70B681EF47AE35131532 1922FD596BF4134847AC.pdf?link=http://www.ingentaconnect.com/ error/delivery\&format $=$ pdf

73. Mehrotra A, Oluwole AM, Gordon SB. The burden of COPD in Africa: a literature review and prospective survey of the availability of spirometry for COPD diagnosis in Africa. Trop Med Int Heal [Internet]. 2009;14(8):840-8. Available from: http://doi.wiley.com/10.1111/ j.1365-3156.2009.02308.x

74. Piddock KC, Gordon SB, Ngwira A, Msukwa M, Nadeau G, Davis $\mathrm{KJ}$, et al. A cross-sectional study of household biomass fuel use among a periurban population in Malawi. Ann Am Thorac Soc. 2014;11(6):90814.

75. Barry AC, Mannino DM, Hopenhayn C, Bush H. Exposure to indoor biomass fuel pollutants and asthma prevalence in Southeastern Kentucky: results from the Burden of Lung Disease (BOLD) study. [Internet]. Journal of asthma. 2010. p. 735-41. Available from: http:// www.ncbi.nlm.nih.gov/pubmed/20716015

76. Agrawal S. Effect of Indoor Air Pollution from Biomass and Solid Fuel Combustion on Prevalence of Self-Reported Asthma among Adult Men and Women in India: Findings from a Nationwide Large-Scale Cross-Sectional Survey. J Asthma. 2012;49(4):355-65.

77. Trevor J, Antony V, Jindal SK. The effect of biomass fuel exposure on the prevalence of asthma in adults in India - review of current evidence. J Asthma [Internet]. 2014;51(2):136-41. Available from: http://www.ncbi.nlm.nih.gov/pubmed/24164361

78. Gunen H, Hacievliyagil SS, Yetkin O, Gulbas G, Mutlu LC, Pehlivan E. Prevalence of COPD: First epidemiological study of a large region in Turkey. Eur J Intern Med [Internet]. European Federation of Internal Medicine; 2008;19(7):499-504. Available from: http://linkinghub. elsevier.com/retrieve/pii/S095362050800040X

79. Abramson MJ, Koplin J, Hoy R, Dharmage SC. STATE OF THE ART Population-wide preventive interventions for reducing the burden of chronic respiratory disease. Int J Tuberc Lung Dis [Internet]. 2015;19(9):1007-18. Available from: http://dx.doi.org/10.5588/ ijtld.15.0034

80. D'Amato G, Liccardi G, D'Amato M. Environmental risk factors (outdoor air pollution and climatic changes) and increased trend of respiratory allergy. J Investig Allergol Clin Immunol [Internet]. Division of Pneumology and Allergology, Azienda Ospedaliera ad Alta Specialità A. Cardarelli, Naples, Italy.; 2000;10(3):123-8. Available from: http://europepmc.org/abstract/MED/10923585

81. Beasley R. Worldwide variation in prevalence of symptoms of asthma, allergic rhinoconjunctivitis, and atopic eczema: ISAAC. Lancet [Internet]. 1998 Apr 25;351(9111):1225-32. Available from: http:// www.sciencedirect.com/science/article/pii/S0140673697073029

82. D 'amato G, Cecchi L, Amato MD', Liccardi G. Urban Air Pollution and Climate Change as Environmental Risk Factors of Respiratory Allergy: An Update. J Investig Allergol Clin Immunol. 2010;20(202):95-102.

83. Bocquier P. World Urbanization Prospects [Internet]. Demographic Research. 2005. 197-236 p. Available from: http://www.demographicresearch.org/volumes/vol12/9/

84. Keeley DJ, Neill P, Gallivan S. Comparison of the prevalence of reversible airways obstruction in rural and urban Zimbabwean children. Thorax [Internet]. 1991 Aug 1;46(8):549-53. Available from: http:// thorax.bmj.com/content/thoraxjnl/46/8/549.full.pdf
85. Hoy R. Occupational asthma in developing countries requires further research. Int J Tuberc Lung Dis [Internet]. 2015 Apr 1;19(4):372-372. Available from: http://dx.doi.org/10.5588/ijtld.15.0129

86. Balmes J, Becklake M, Blanc P, Henneberger P, Kreiss K, Mapp C, et al. American Thoracic Society Statement. Am J Respir Crit Care Med [Internet]. 2003 Mar 1;167(5):787-97. Available from: http://www. ncbi.nlm.nih.gov/pubmed/12598220

87. Aguwa EN, Okeke T a, Asuza MC. The prevalence of occupational asthma and rhinitis among woodworkers in south-eastern Nigeria. Tanzan J Health Res [Internet]. 2007 Jun 7;9(1):52-5. Available from: http://www.ajol.info/index.php/thrb/article/view/14293

88. Ballal SG. Respiratory symptoms and occupational bronchitis in chromite ore miners, Sudan. J Trop Med Hyg [Internet]. 1986 Oct;89(5):223-8. Available from: http://www.ncbi.nlm.nih.gov/ pubmed/3795322

89. Musafiri S, Joos G, Van Meerbeeck JP. Asthma, atopy and COPD in sub-Saharan countries: the challenges. East Afr J Public Health [Internet]. 2011;8(2):161-3. Available from: http://ovidsp.ovid. com/ovidweb.cgi? $\mathrm{T}=\mathrm{JS} \& \mathrm{PAGE}=$ reference $\& \mathrm{D}=$ medl $\& \mathrm{NEWS}=\mathrm{N} \&$ $\mathrm{AN}=22066305$

90. Denguezli M, Daldoul H, Harrabi I, Gnatiuc L, Coton S, Burney $\mathrm{P}$, et al. COPD in Nonsmokers: Reports from the Tunisian PopulationBased Burden of Obstructive Lung Disease Study. Behrens T, editor. PLoS One [Internet]. 2016 Mar 24;11(3):e0151981. Available from: http://dx.plos.org/10.1371/journal.pone.0151981

91. Mahboub B, Alzaabi A, Soriano JB, Salameh L, Mutairi Y AL, Yusufali AA, et al. Case-finding of chronic obstructive pulmonary disease with questionnaire, peak flow measurements and spirometry: a cross-sectional study. BMC Res Notes [Internet]. 2014;7(1):241. Available from: https://www.scopus.com/inward/record.url?eid=2s2.0-84899472456\&partnerID=40\&md5=edc6f0027d683a41a41ed554 f0e67745

92. Willcox PA, Ferguson AD. Chronic obstructive airways disease following treated pulmonary tuberculosis. Respir Med [Internet]. 1989;83(3):195-8. Available from: http://www.sciencedirect.com/ science/article/pii/S0954611189800319

93. Plit ML, Anderson R, Van Rensburg CEJ, Page-Shipp L, Blott JA, Fresen JL, et al. Influence of antimicrobial chemotherapy on spirometric parameters and pro-inflammatory indices in severe pulmonary tuberculosis. Eur Respir J [Internet]. 1998 Aug 1;12(2):3516. Available from: http://erj.ersjournals.com/content/12/2/351

94. Ehrlich RI, White N, Norman R, Laubscher R, Steyn K, Lombard $\mathrm{C}$, et al. Predictors of chronic bronchitis in South African adults. Int J Tuberc Lung Dis [Internet]. 2004 Mar;8(3):369-76. Available from: http://www.ncbi.nlm.nih.gov/pubmed/15139477

95. SHIRTCLIFFE P, WEATHERALL M, BEASLEY R. An inverse correlation between estimated tuberculosis notification rates and asthma symptoms. Respirology [Internet]. 2002 Jun;7(2):153-5. Available from: http://doi.wiley.com/10.1046/j.1440-1843.2002.00372.x

96. Calligaro GL, Gray DM. Lung function abnormalities in HIVinfected adults and children. Respirology [Internet]. 2015 Jan;20(1):2432. Available from: http://doi.wiley.com/10.1111/resp.12385

97. Gingo MR, Morris A, Crothers K. Human Immunodeficiency VirusAssociated Obstructive Lung Diseases. Clin Chest Med [Internet]. 2013 Jun;34(2):273-82. Available from: http://linkinghub.elsevier.com/ retrieve/pii/S0272523113000415

98. Hegewald MJ, Crapo RO. Socioeconomic Status and Lung Function. Chest [Internet]. 2007 Nov;132(5):1608-14. Available from: http://linkinghub.elsevier.com/retrieve/pii/S0012369215512786

99. Prescott E, Vestbo J. Socioeconomic status and chronic obstructive pulmonary disease. Thorax [Internet]. 1999 Aug 1;54(8):737-41. Available from: http://thorax.bmj.com/cgi/doi/10.1136/thx.54.8.737 
100. Pallasaho P, Lindström M, Põlluste J, Loit H-M, Sovijärvi A, Lundbäck B. Low socio-economic status is a risk factor for respiratory symptoms: a comparison between Finland, Sweden and Estonia. Int J Tuberc Lung Dis [Internet]. 2004 Nov;8(11):1292-300. Available from: http://www.ncbi.nlm.nih.gov/pubmed/15581195

101. Thomsen SF. Epidemiology and natural history of atopic diseases. Eur Clin Respir J [Internet]. 2015;2:1-6. Available from: http://www. ecrj.net/index.php/ecrj/article/view/24642/39132

102. Mabey D, Gill G, Whitty CJM, Weber MW. Principles of Medicine in Africa [Internet]. Cambridge University Press; 2013. Available from: https://books.google.com/books?id=RDWFo45IAxcC

103. D'Amato G, Holgate ST, Pawankar R, Ledford DK, Cecchi L, Al-ahmad $\mathrm{M}$, et al. Meteorological conditions , climate change , new emerging factors, and asthma and related allergic disorders . A statement of the World Allergy Organization. World Allergy Organ J [Internet]. World Allergy Organization Journal; 2015;1-52. Available from: http://dx.doi.org/10.1186/s40413-015-0073-0
104. Fullerton DG, Gordon SB, Calverley PM. Chronic obstructive pulmonary disease in non-smokers. Lancet (London, England) [Internet]. Elsevier Ltd; 2009 Dec 12;374(9706):1964-5-6. Available from: http:/www.ncbi.nlm.nih.gov/pubmed/20006126

105. Uzaslan E, Mahboub B, Beji M, Nejjari C, Tageldin MA, Khan JA, et al. The burden of chronic obstructive pulmonary disease in the Middle East and North Africa: Results of the BREATHE study. Respir Med [Internet]. Elsevier Ltd; 2012;106:S45-59. Available from: http:// linkinghub.elsevier.com/retrieve/pii/S0954611112700148

106. Sánchez-Borges M, Capriles-Hulett A, Caballero-Fonseca F. Asthma Care in Resource-Poor Settings. WAO Journal. 2011. p. 68-72. 